\title{
Towards Transition Management of European Water Resources
}

\author{
Published in J ournal Water Resource Management, \\ Special issue: Advances in global Change Research
}

\author{
Rutger van der Brugge, J an Rotmans
}

\begin{abstract}
Global change fundamentally changes the nature of water-related problems. We will illustrate this by showing how perceptions of the water-problems in the Netherlands have shifted in the past four decades. The nature of water-related problems changed from a technical problem' to a so-called 'persistent' problem, characterized by plurality, uncertainty and complexity. Although integrated water resource management (IWRM) has been advocated to cope with this type of problem, the complexity of the transition process towards such a water management regime is often underestimated. Therefore, transition management is needed in the water sector. Transition management theory is presented and applied to the Dutch case. Transition management strategies are suggested that would reinforce this transition. Comparison between the European Water Framework Directive (WFD) and transition management indicates that the Common Implementation Strategy (CIS) in its current form is not sufficiently stimulating an innovation climate.
\end{abstract}

Keywords: transition management, integrated water resource management (IRWM), European Water Framework Directive (WFD).

\section{Introduction}

Our world is rapidly changing. Human induced climate change is expected to have profound consequences on large parts of the world. Especially the impacts on large aquatic systems - upon which many people depend - pose a considerable threat to current and future generations. However, due to the high complexity of this problem, that is the many interactions between atmospheric processes, hydrological processes and ecosystem processes, it is impossible to calculate local impacts accurately. Bearing this in mind, water managers are now analyzing the possibilities to create adaptive water systems that are more resilient to extreme impacts.

Global change not only affects the water management strategies, but also changes the nature of water-related problems. The interconnectedness of different water functions reflects the increasing complexity of our modern society. Economic functions for navigation, agriculture and energy supply, ecological functions for sustaining ecosystems, and social functions in terms of safety and drinking water supplies are without exception of critical importance to our modern society. Reinforcing one particular function may have adverse effects on others as a result of (often unknown) feedbacks. Policy-makers, as well as water managers cannot afford 


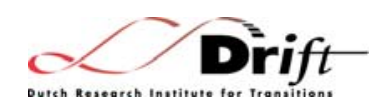

to be ignorant about societal functions 'outside their own box'. Moreover, different types of values that can be attributed to water complicate the decision-making process itself. How does one attribute the just weights to the economic values of water (utility value of water by using pricing mechanisms) the ecological values (water regulation services for ecosystem sustainability) and the cultural values and emotional meaning of water? Modern water management is thus confronted with a complex, uncertain and pluralistic problem.

Integrated water resource management (IWRM) has been advocated to cope with this type of problem. In this respect, the European Union Water Framework Directive (2000/60/EC) is considered to be an important landmark. The Water Framework Directive (WFD) has been put forward as a legislative framework to guarantee the 'good quality of all waters in Europe'. Besides the scale to which it applies, which is unprecedented (and that alone makes it worthwhile to analyze its implementation), the Directive introduced two important new aspects: the river basin approach and stakeholder involvement. The first aspect is of course a prerequisite for the integration of water management strategies up- and downstream. The latter addresses the plurality of objectives and values by involving stakeholders in the river basin management plan. It thereby addresses and confronts many of the difficulties of integrated trans-boundary water management. The Directive thus is a strong impetus for integration and cooperation in European water management. However, one of the weak points is that the WFD does not address water quantity issues, which in terms of climate change is indeed a very serious omission.

Although the WFD thus addresses important first steps in the transition process, it does not sufficiently address the transition process itself. Water quantity issues ask for even more fundamental rethink about water management because these issues presuppose a very tight relation with spatial planning, e.g. spatial planning policies have to be incorporated in the river basin management plan. However, conditions have to be created in which this can be done and in which innovations can be developed. For example, in the Netherlands one clearly sees this process unfolding. Having a large coastal zone and embracing the river delta of two large European rivers, its water managers are particularly forced to make adaptations in the water system in order to deal with sea-level rise and extreme river discharges as a result of climate change. Much effort goes into the institutional integration of the policy fields of spatial planning and water management, but the actual implementation is very difficult.

Even though we focus in this article on the Dutch case, understanding the particular case of the Netherlands may provide insights into the general nature of the transition processes in the EU-Member States and European water management as a whole. We also try to present a more general analytical framework based on the theory of transitions and transition management (Rotmans et al., 2000) and show that the problems that now arise in the river basins are of a more general nature, inherently related to transition processes. We will apply the basic principles underlying transition management to EU water management and from this perspective reflect on the WFD and explore to what extent these principles can be used within the context of the WFD. 


\section{The nature of the Dutch water problems}

Although approximately $60 \%$ of the Dutch soil is beneath sea level, an intricate web of dams, channels, pumps and polders keeps the inhabitants' feet dry. However, full attention is required twenty-four-seven. Nonetheless, the water problems are manifold. In 1993 and 1995 the nation got shocked when the rivers Meuse and Rhine almost flooded and thousands of people had to be evacuated. After this major but rather surprising incident more problems followed, amongst others large agricultural damages in the western part of Holland due to high water levels in 1998 and the 2003 flooding in Wilnis. Besides water abundance, other problems related to water have been drought, industrial cooling water and water pollution. Although, these waterrelated problems may seem to be singular, they are in fact interrelated and connected, merely manifestations of a deeper lying more fundamental cause.

These water-related problems are specific manifestations of a deeper-lying, more fundamental problem. The growing economic development, increasing population and changing life-styles of the $20^{\text {th }}$ century have led to pressures on the water system through increasing spatial claims from agriculture, industry, traffic, housing and infrastructure. In the attempt to meet these increasing societal demands, water engineers fabricated a skillfully branched water system consisting of canals, dikes and polders. The human controlled water system resulted in altered hydrological cycles and morphological changes. Its slow development has put increasing pressure on space, hydrology, morphology, subsidence of soil and capacity to retain water. Although these interventions were absolutely necessary, the negative consequences that stayed concealed for a long time are now surfacing. Unless these pressures are released, in the future both the magnitude and frequency of water related problems will increase.

Viewed from this angle, the water problems are local manifestations with similar underlying (autonomous) driving forces. They are so-called persistent problems and can be characterized by on the one hand the complexity of the interactions of broad societal trends and physical (natural) processes (such as climate change), which gives rise to structural uncertainty and on the other hand by the involvement of many stakeholders with different but plausible perspectives, which leads to problems of management and governance (Dirven, Rotmans, \& Verkaik, 2002). The persistence itself is caused by the strong interconnectivity between water institutions, management structures, routines and techniques. This results in a tight and wellorganized water management regime, involving policy departments, regional water management boards, engineering offices, scholars and jurists. Due to its interdependencies and internal logic regime structures are often difficult to change and radical innovations have trouble breaking through.

What does this mean for modern water management practice? First, it means that society has to reconsider the way water functions are weighted and prioritized. Secondly, water management decision-making should be based on balanced integration frameworks and address different scale levels both in space and time. Thirdly, the current institutional arrangement, which is a barrier for the first two, needs to be changed. Transition management is one of the approaches proposed in the 
literature to deal with persistent problems. In the following sections we will present transition theory and apply it to the observed shift in Dutch water management (Van der Brugge, Rotmans, \& Loorbach, 2005).

\section{Transition theory}

(Rotmans et al., 2000) have introduced the concepts of transition and transition management as new integrative approach in the field of sustainability and governance in order to deal with persistent problems. The transition framework offers analytical tools for structuring and explaining the dynamic behavior of societal systems, such as the transport sector, energy supply and agriculture, or water management. Transition management attempts to influence, facilitate, stimulate and organize processes that contribute to the transition. They define a transition as 'a continuous process of societal change, whereby the structure of society (or a subsystem of society) fundamentally changes and has the following characteristics:

- It concerns large scale technological, economical, ecological, socio-cultural and institutional developments that influence and reinforce each other;

- It is a long term process that covers at least one generation (25 years);

- There are interactions between different scale levels (niche, regime, landscape).

The transition framework is rooted in complex adaptive systems (CAS) theory (Holland, 1995; Kauffman, 1995; Prigogine \& Stengers, 1984) post-normal science (Ravetz, 1999), integrating concepts from governance (Sabatier \& J enkins-Smith, 1999), evolutionary economics (Arthur, 1988; Nelson \& Winter, 1982), innovation studies (Smits \& Kuhlmann, 2004) and technological transitions (Geels \& Kemp, 2000). Transitions are often illustrated as S-shaped curves (Figure 1). Although this is a very simple aggregated curve, the underlying transition dynamics are complex interaction processes between markets, networks, institutions, technologies, policies, individual behavior and autonomous trends in the economic, ecological, sociocultural and institutional domain. From a CAS perspective, transitions are system transformations between two temporal (dynamic) equilibrium states (attractors). In between there is a period of rapid change during which the system undergoes irreversible re-organization (Rotmans, 1994). 


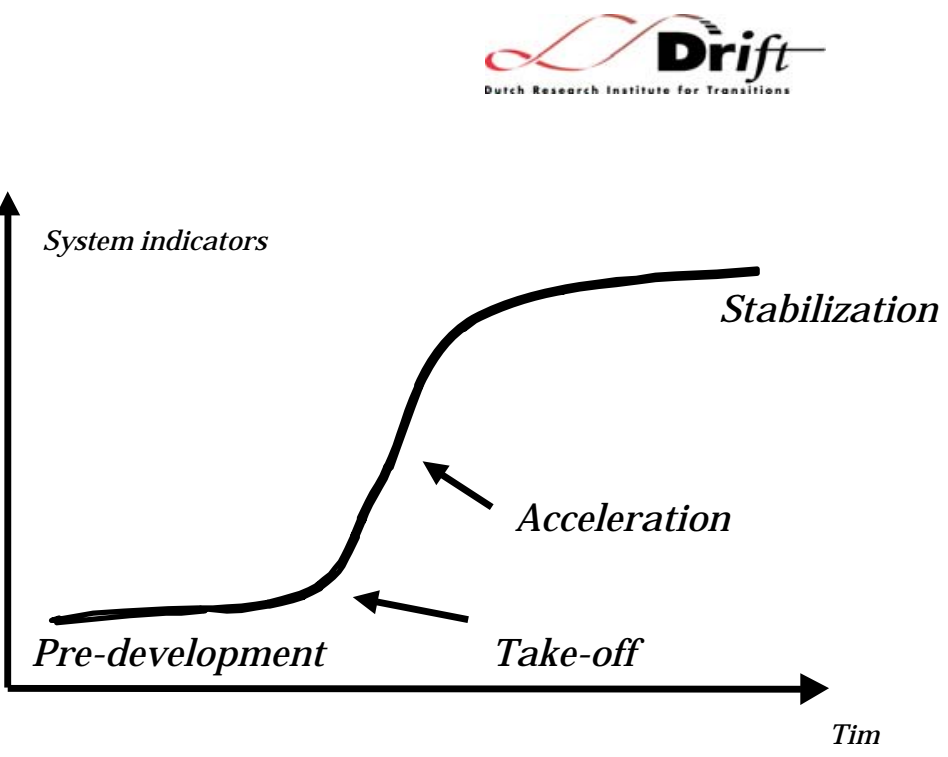

Figure 1. A transition is the shift between two dynamic equilibria that can be described by a set of system indicators. In the transition process, four phases can be distinguished. In the predevelopment these indicators change only marginally. In the take-off and acceleration phase the indicators change with increasing speed. In the stabilization a new equilibrium is reached (Rotmans et al., 2002).

The transition framework comprises three analytical tools in order to recognize and explain transition patterns. These are:

(1) multi-phase concept: a transition is a sequence of the following four phases: predevelopment, take-off, acceleration and stabilization (fig 1.).

(2) multi-level concept: a transition is the result of interacting developments at macro-, meso- and micro-level (fig 2.).

(3) multi-change concept: during a transition new structures emerge and existing structures are broken down.

According to (Rotmans et al., 2000) the general pattern of evolution during the four phases is the following. In the pre-development phase, the system dynamics do not change visibly but stocks are slowly changing. In the take-off phase, the structure of the system begins to change as the result of (1) the emergence of innovations and (2) destabilization of the existing regime. In the acceleration phase, structural transformation of the system takes place. New patterns of system dynamics emerge as a result of accumulation of socio-cultural, economic, ecological and institutional changes innovations that reinforce each other. In the stabilization phase the new pattern of system dynamics reaches a new dynamic equilibrium.

Transitions only unfold when developments at the macro level, meso-level and microlevel 'move into the same direction' (Geels \& Kemp, 2000; Rotmans et al., 2000). Geels and Kemp have developed this multi-level perspective to describe and explain transitions in large technological systems and later applied it to sustainability transitions (figure 2). At the macro-level the landscape' is determined by changes in the macro-economy, politics, population dynamics, natural environment, culture and world views. This level responds to relative slow trends and large-scale developments that canalize the evolution of a particular societal system, although catastrophic events, such as tsunamis or terrorist attacks can almost instantly change (parts of) the (political) landscape. At the meso-level there are patterns of institutions, artifacts, rules and norms assembled and maintained to perform economic and social activities 
which is referred to as the 'regime' (Berkhout, 2003) At the micro-level there are socalled 'niches' of individual actors, alternative technologies and local practices that deviate from the status quo manifesting themselves as new ideas, initiatives or innovative techniques (Kemp, Schot, \& Hoogma, 1998).

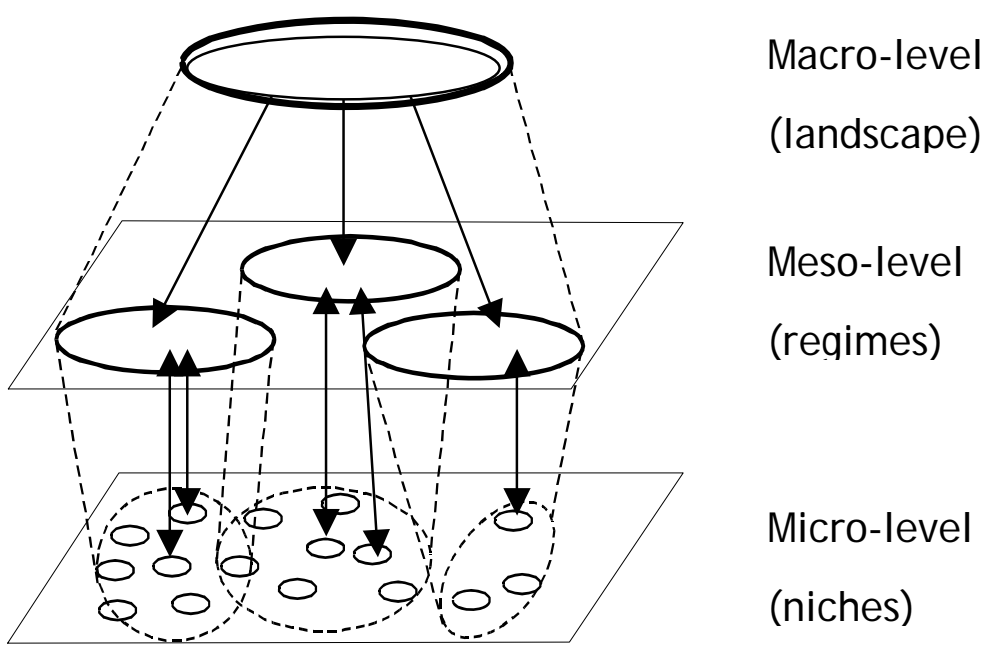

Figure 2. Multi-level concept is based on (Geels and Kemp, 2000). Developments at the macro-level correspond to slow broad societal trends. Dynamics at the meso-level are determined by the regime. The regime is the dominant pattern of actors, artifacts and structures in the social system. At the micro-level, individual persons, organizations, or innovations are distinguished.

\section{Complex Adaptive Systems}

The typical division between (a) dominant structure at the middle level, (b) alternatives at smaller level and (c) long-term trends at the higher-level has proven to be a reasonable framework to describe transformation of the regime structure as a result of bottom-up innovations and changing landscape factors in retrospect. The regime can be seen as a complex adaptive system (Table 1.), viewing it as an island of relative stability embedded in a changing landscape and not always capable of adapting due to its interdependencies between its actors and artifacts. Regime dynamics are very much dominated by strong internal relations and relatively weak external relations. Its internal dynamics are deeply embedded in social interactions and are consequently difficult to change. New agents trigger change by developing their own niche. Through increasing network externalities these niches become increasingly attractive to other agents (Arthur, 1988). Niches can break trough when macro socio-environmental conditions are favorable.

\section{Properties of Complex Adaptive Systems}

- Many and divers components and interactions

- Components are organized in a network configuration

- The system is open (exchange of matter, energy and information with external environment) 
- Non-linearity

- Positive and negative feedback loops (reinforcing and dampening mechanisms)

- Nested organizational levels

- Multiple attractors (relative stable but dynamic equilibrium states) co-exist

- Attractors have stability domains, bounded by thresholds

- Components are able to learn and respond to the environment by changing behavior (interactions)

- Co-evolutionary interaction patterns may lead to irreversible pathways

- Higher level structures spring into being as result of lower level component interaction

Table 1. Properties of complex adaptive systems (CAS), based on (Prigogine \& Stengers, 1984)(Holland, 1995; Holling, 1987; Kauffman, 1995). These properties apply to social systems, leading to the conclusions that social systems are complex adaptive systems and that the behavior of this category of systems may have general features.

Typical of CAS is pathdepedency. When formed, the regime is able to maintain and reproduce its internal dynamics. Only when certain thresholds are exceeded, the equilibrium structures break and the adaptive system transforms. (Gersick, 1991) argues that disruption of the equilibrium has two sources: (1) internal changes that pull parts and actions out of alignment with each other or the environment, and (2) environmental changes that threaten the system's ability to obtain resources. Generally speaking, transitions are the result of two mutually reinforcing mechanisms: (1) destabilization of the regime on the one hand and (2) the emergence and up-scaling of innovations on the other. When both are absent the system is in equilibrium. In the acceleration phase they mutually reinforce each other strongly, leading to very rapid dynamics. Macro socio-environmental conditions can affect the mechanisms both ways. Describing transition of complex adaptive systems in terms of phases and multilevel interactions patterns yields the following dynamic pattern (fig 3):

\section{Phase 1. Predevelopment $\rightarrow$ Approaching 'criticality'}

During the predevelopment phase, co-evolutionary regime dynamics increase regime interdependencies and as a result, the regime organization approaches criticality. Resilience decreases and the regime structure becomes increasingly vulnerable. Changing socio-environmental conditions impose stress on the regime structure, demanding efforts from actors in performing their functions in the supply-chain, policy or regulation domain. Innovations are still isolated and fragmented, improperly embedded and insufficiently developed enough to compete with the existing regime.

\section{Phase 2. Take off $\rightarrow$ Triggering change and Build up of new regime}

During the take off phase, the regime grows 'critical' and innovations start acting as perturbation of the status quo, triggering large scale change. As the system becomes increasingly 'critical', calamities affect all system domains due to high interconnectivity. In non-critical systems, calamities only have local effects. The same holds for innovations, which explains why is it so hard for them to break trough if the 
system is near criticality. Regime structures must first open up before innovations have a chance of penetrating the system. Regime dynamics collapse when the systems key functions fall out. This may be the case when existing actors do not perform adequately. Simultaneously, there is build-up of innovation networks based on alternative ideas, concepts, theories and technology, which may lead to alternative behavior. Innovations must reinforce each other and align into innovation networks, which is a perquisite for behavioral change. Developing the network requires access to resources, like for example money and knowledge (e.g. the societal equivalents of nutrients and energy needed by biological systems to maintain homeostatic organization) in order to develop its assets. If the innovation network succeeds in becoming self-sustaining, in terms of maintaining and reproducing its own organization ${ }^{1}$ it has survival advantages over innovations that do not cluster into selfsustaining networks.

Depending on co-evolutionary developments in the regime on the one hand, and the 'survival fitness' of the available attractors on the other, there can be three pathways (1) there remains a co-existence of more competing innovation networks (lock-in), (2) there is only one innovation network, which is reinforced by smaller innovation networks enabling it to grow (acceleration), or (3) there is a more or less chaotic world in which innovation networks are all insufficient in becoming self-sustaining and keep competing for the same resources. As a result, there is no adequate substitute for the destabilizing regime (system breakdown).

\section{Phase 3. Acceleration $\rightarrow$ Cascading effects}

During the acceleration it becomes clear which innovation networks are'fittest' and consequently are selected. Fitness is a relative term, referring to the survival chances of the innovation network in a co-evolving environment. Thus while the innovation networks compete for resources with each other, they simultaneously are influenced by destabilizing regime developments. Co-evolution in the end determines the outcome as a result of recursive developments between the macro developments, regime developments and innovations at the micro-level. During this phase, the 'old' regime transforms and consequently the 'selection environment' changes and is primarily based upon selection rules from the up-scaled innovation network.

\section{Phase 4. $\rightarrow$ Stabilization}

During the stabilization the new regime settles down. Transformation processes turn into optimization processes. Regime dynamics now are equilibrium dynamics in order to enhance efficiency. If this equilibrium is not reached, the new regime can still breakdown (backlash).

1 This capacity of biological systems to be able of reproduction their own organizations is referred to as autopoiesis (Varela, Maturana, \&Uribe, 1974). H. Maturana later applied this to social systems as did sociologist Niklas Luhmann (Luhmann, 1984) 


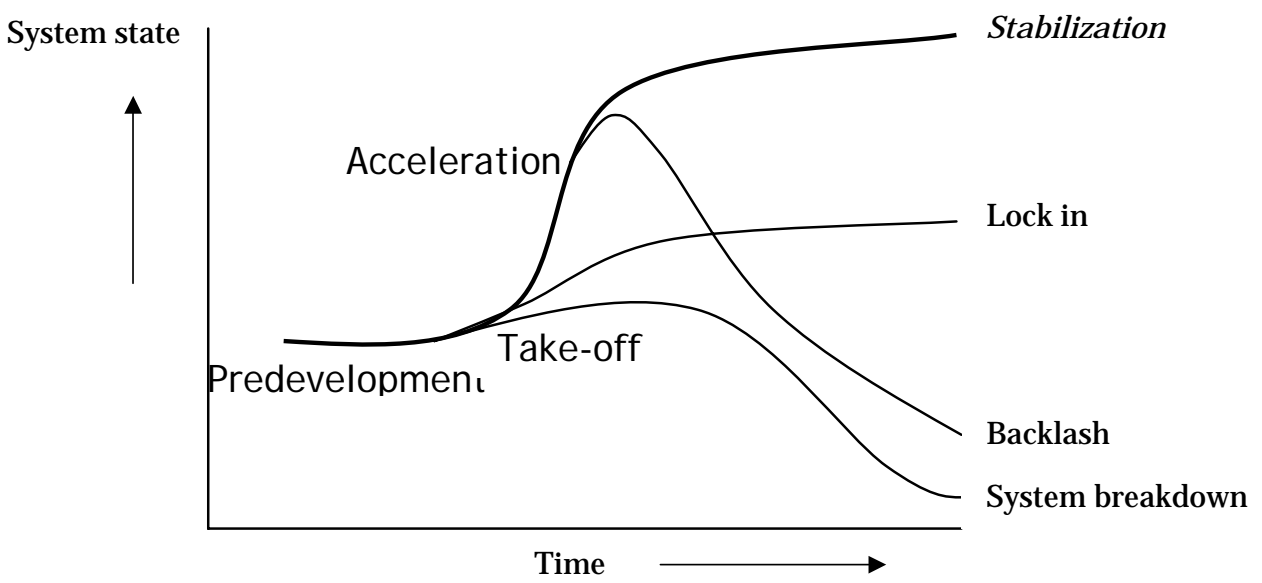

Figure 3. Possible system pathways of a complex adaptive societal system. The transition is the desired pathway in achieving sustainable development. However, the complexity of the interaction processes limits control over societal developments which may lead to less desired pathways, such as the lock-in, the backlash or the system breakdown.

\section{Transition dynamics in Dutch Water management}

The transition heuristic can be applied to the shift in Dutch water management from a scientific technocratic water management regime (Bosch \& Ham, 1998; Ham, 1999; Lintsen, 2002) towards the integrated water management regime. Integrated water management (Saeijs, 1991) perceives water as part of a larger system, integrating engineering and ecological aspects into a broader societal system. This changing scope of water management is strongly reflected in subsequent National Policy Memoranda on Water Management (Rijkswaterstaat, 1964, 1982, 1989, 1998). Picking up the early signs, this change started around 1965 with the emergence of an environmental movement (Van der Brugge et al., 2005). Since then, Dutch water management changed in terms of prioritizing water functions as well as in terms of safety strategies and since then, ecological functions of water became increasingly important, while the traditionally influential role of agriculture declined. Also, water managers now tend to broaden the riverbed and prohibit housing or economic activity in the river floodplains, instead of constructing dykes as a means to protect the people and investments. Slowly national water policy measures encouraged the integration of spatial planning and water management. Today, water is postulated a 'guiding principle for spatial planning'. As opposed to the 1960's, the properties of the water system are now assumed to be guiding socio-economic activity. Essentially, this means $180^{\circ}$ turn in the relationship between water management and spatial panning. This clear fundamental break with tradition has, however, not yet reached a new equilibrium (Van der Brugge et al., 2005)Applying the transition heuristic to the evolution of water management provides insight in which phase the transition is currently.

\subsection{The predevelopment phase}

Traditionally, water-related problems were being solved using technological means. Being an engineer, the core competences of the water manager were the construction 


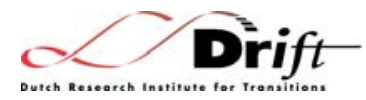

of water infrastructure and calculating water flows. The management style was enabled through a scientific and technocratic regime that reigned throughout the 20th century (Bosch \& Ham, 1998; Ham, 1999; Lintsen, 2002). This equilibrium can be overly simply sketched as the 'Water will follow' attractor ${ }^{2}$. The system dynamics were that of growing economic development, increasing population density and changing life-styles that were leading to increasing spatial claims of agriculture, industry, traffic, housing and infrastructure. In the attempt to meet these societal needs, water managers drained redundant water, canalized rivers and constructed dams, e.g. water 'followed' societal needs. The significant interventions in the water system could only be managed, maintained and controlled by continuing its technological mode of operating, manoeuvring itself onto this technological trajectory. As such, problems were being perceived as singular technological problems and technological solutions did not solve the problem on a more fundamental level, namely removing the pressures upon the system. Due to this path dependent management style, the financial costs of problems such as floods, droughts and diminishing water quality increased. As efficiency and cooperation initially countered these pressures and more complex governance structures came into existence trying to couple multiple scales, the water management system was approaching its spatial and economic thresholds.

\subsection{Take-off $\rightarrow$ Triggering change}

After the 1993 and 1995 floods of the rivers Meuse and Rhine, an increasing number of people started to understand that the 'Water will follow' attractor had resulted in an unsustainable water system and that the problems were symptoms of the system exceeding its thresholds. Followed by high regional water levels in 1998 the perspective about water management started to change. The Committee Water management for the $21^{\text {st }}$ century' claimed that Dutch water management was not sufficiently prepared to meet the challenges of climate change effects in the next century' (EC). The continuous subsidence of soil, the rising sea level and the decreasing capacity to retain water due to loss of nature would cause serious problems. The committee expected climate change to contribute to extreme events and higher discharge levels during winter while lower during summer. On the whole, strategists started to recognize the inherent problems of the current system and to acknowledge the spatial claim of water itself. They considered the way towards a more adaptive water system in order to anticipate future threats. The Committee proposed a new water management strategy based on two starting points: (1) water had to be guiding in spatial planning, and (2) water had to be retained, stored and drained when necessary.

\footnotetext{
${ }^{2}$ Although the term 'attractor' has a specific meaning in systems theory, being the endpoint of a systems evolutionary trajectory (often illustrated in phase space), its meaning here is the range of management actions allowed by the regime. The water manager acts while it is constrained and at the same time enabled through its regime structures, leaving a limited set of choice options than are theoretically possible. In effect, locking the system in a subset of phase space.
} 


\subsection{Take-off $\rightarrow$ Build up of the new regime}

Many events, plans and developments have contributed to the visionary report of the Committee 'Water management for the $21^{\text {st }}$ century'. Its foundations can be traced back to the late 1980's (Van der Brugge et al., 2005). In a way, from there on, its history can be summarized as increasingly integrating different functions, with a strong emphasis on ecology and later on spatial planning. So, what is interesting here is the way in which these two discourses penetrated the water management practice.

\subsubsection{The emergence of ecological orientation}

In order to prevent a crisis such as the 1953 Storm flood, Rijkswaterstaat (the ministry of water management) started an ambitious water defense program, the Delta Works. The Delta Works are a set of dams that have to protect the Dutch from the sea. The large dams had profound adverse effects on nearby ecosystems. Salt water based ecosystems had evolved into fresh water ecosystems, leading to dramatic consequences in local biodiversity (Bosch \& Ham, 1998). Therefore the Delta Dienst, (the formal institute responsible for the construction of the Delta Works) founded an environmental department concerned with ecological research headed by H. L. F. Saeijs. A biologist himself, he brought over a hundred fellow biologists into the engineering world of water management. The research activities performed by the Delta Dienst led to a number of restoration projects. In 1985, the policy memorandum Dealing with Water' (RIZA, 1985) reported important elements of the ecological approach in water management. It reached a wide audience, partly due to the ecological calamities evoked by the Delta Works. The (eco)systems approach advocated in this document represented a new perception proposing water as an integral part of an ecosystem in relation with its community (Saeijs, 1991)

Important reasons explaining why the ecological perspective resonated in the water management regime was the involvement of a growing number of biologists. During the construction of the Eastern Scheldt storm surge barrier, one of the most prestigious dams, the Environmental Department of the Delta Dienst had grown into a group of over one hundred biologists and confronted the regime with the consequences of its practices (Bosch \& Van der Ham, 1998). This in fact was a strong destabilizing factor in the regime as were the protests of the environmental movement. In the 1980's re-organization of the Ministry in order to integrate water quantity and water quality policies, many former Delta Dienst biologists were placed on strategic positions. Cross-fertilization between biologists and water engineers 'infected' Rijkswaterstaat with new ideas.

Another impetus towards the integration of ecological considerations and water management was provided by the award-winning plan 'Ooievaar' (Bruijn et al., 1987) in a contest that was called 'Netherlands - Riverland' (organized by the E.O. Wijers Institute). The contest invited participants to come up with ideas about future water management. 'Ooievaars' vision departed from decoupling agriculture and nature preservation, claiming that agriculture was damaging and not preserving ecosystems. 'Ooievaar' in this sense broke with prevailing beliefs and questioned the (traditional) influence of agricultural demand in water management. In short, 'Ooievaar' planned the removal of agricultural exploitation in the river flood plains and instead created 


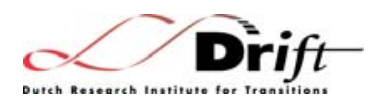

the original meandering riverbanks, rich of plants and animals. A number of 'Ooievaar' based experiments were started with success in different regions, e.g. the Duursche Waarden, in Rhenen and the Gelderse Poort (Bosch \& Ham, 1998). The minister was quite fond of the plan, informing the media she had an alternative for expensive dikes along the river.

\subsubsection{The emerging link with spatial planning}

It was not before the end of the 80's that serious and conscious attempts were made to integrate the two policy fields of spatial planning and water management. Meaningful in this respect is the WWF-plan 'Levende Rivieren (WWF, 1992) Levende Rivieren' ('Living Rivers') elaborated from 'Ooievaar' with stronger focus on the aquatic ecosystem and its flora and fauna. Wanting to restore broken food chains, 'Levende Rivieren' proposed the introduction of smaller channels in the river flood plains and by doing this it showed an alternative to planned dike enhancements. Small channels and excavation of clay-layers in the river floodplains would create more room for water and could thus present an alternative safety strategy to dike enhancements. Prior to that, smaller groups within Rijkswaterstaat had also explored the possibilities of integrating water policy with spatial planning, one of them resulting in the report 'Omgaan met de Omgeving' (Rijkswaterstaat, 1992). 'Omgaan met de Omgeving' ('Dealing with the Surrounding Area') initiated a number of interdepartmental meetings of top officials discussing the future of this path of integration.

\subsubsection{Co-evolving mechanisms}

The above-described innovative plans can be interpreted as the innovation networks which laid down the foundations of a new water management regime, having a strong focusing on spatial integration of different water functions. Three important developments at the macro-level that reinforced the innovation networks in destabilizing the techno-scientific regime were (1) the emergence of the environmental movement creating an awareness about environmental pollution, which has led towards a more ecologically oriented approach; (2) the perception of flood risk had drastically changed after the floods and what initially were merely ambitions to integrate water practices and spatial planning, now had grown rapidly into a sense of urgency; (3) decentralization and privatization since the 1980's resulted in a shift of power that weakened the hierarchical structure in the water sector. Two important regime developments that have led to the institutionalization of the ecological approach have been the reorganization of Rijkswaterstaat, which offered ecologists positions within the ministry and the merger of the regional water management boards. Larger management units allowed for integration between quantity and quality measures. Both initiatives have had serious effects on the institutional arrangements in the sector.

In summary (Table 2 and 3), the innovation networks came into existence in a changing landscape in which two new discourses emerged: (1) the inherent relation between ecology and water management (water quality policy) and (2) between spatial planning and water management (water quantity policy), and at the same time enabling this landscape by transferring it into new approaches. Both discourses have 
been reinforced by crises, such as the ecosystem damage induced by the Delta Works, and the floods of 1993 and 1995. The current transformation dynamics in Dutch water management are foremost the attempts of innovating issues concerning water quantity.

\subsection{Acceleration?}

We demarcate the acceleration phase as the point in time when the selection rules for policy and implementation change according to the wishes of the emerging regime. Thus, there is a transfer of selection power from the traditional regime towards the new regime. Although this appears to be the case with the report Water management for the $21^{\text {st }}$ century', in practice it is not. The logic and coherence of the concepts at the (strategic) abstract level is the strength of the report, however, in the real world there are many practical hurdles. The selections rules are still very much unclear. For instance, there is need of institutional renewal in terms of actors, responsibilities and tasks; there is need of technology and scientific knowledge, possibly new regulations regarding land ownership and insurance etc. Illustrative in this respect are the 'water test' which secures that water is taken into account in spatial planning policy, debates about designating flood areas and debates about merging regional water management with provincial layers of government. Debates are ongoing and although the outcome is not crystal clear, its direction might be. The strategy seems to be widely acknowledged, but the actual implementation is difficult and consequently the actual physical and institutional changes are issues of debate. The regime is in the middle of a process of re-configuration, which requires alternative modes of operating, cooperation and regulation. Hence the transition is still in the middle of the transformation process between the two regime attractors. The choices that are now being made are very much decisive for the trajectory of the transition. 


\begin{tabular}{|c|c|c|c|c|c|c|}
\hline System state 1975 & Events & System state 1985 & - $\quad$ Events & System state 1995 & Events & System state $\mathbf{0 5}$ \\
\hline Supranational & $\begin{array}{ll} & \text { Growing } \\
\text { environmental } \\
\text { awareness } \\
- & \text { Economic growth } \\
- & \text { Limits to Growth }\end{array}$ & & - $\quad$ Rio Summit ('92) & & \begin{tabular}{ll|}
- & J ohannesburg \\
summit ('02) \\
- & Climate Change \\
- & Sea level rise \\
- & EU Water Framework \\
& Directive
\end{tabular} & \\
\hline National & $\begin{array}{llr}- & \text { Delta } & \text { Works } \\
\text { Calamities (ecological } \\
\text { impact) }\end{array}$ & & $\begin{array}{llr}- & \text { lst } & \text { National } \\
& \text { Environmental Policy } \\
& \text { Plan } \\
- & \text { lst Nature Policy Plan } \\
- & \text { Floods ('93, '95) } \\
\end{array}$ & & $\begin{array}{ll} & \text { National } \\
\text { Environmental Policy } \\
\text { Plan 2,3,4 (NMP2-4) } \\
\text { Environmental } \\
\text { Management Act } \\
\end{array}$ & \\
\hline $\begin{array}{l}\text { Technocratic } \\
\text { water } \\
\text { management }\end{array}$ & \multirow{3}{*}{$\begin{array}{ll} & \text { Delta Works } \\
\text { - } & 2^{\text {nd }} \text { National Policy } \\
\text { Memorandum Water } \\
\text { Management } \\
\text { Protests against water } \\
\text { management } \\
\text { approach }\end{array}$} & \begin{tabular}{ll|} 
Water System \\
management
\end{tabular} & $\begin{array}{lll}- & 3^{\text {rd }} & \text { National Policy } \\
\text { Memorandum Water } \\
\text { Management ('89) }\end{array}$ & $\begin{array}{ll}\text { Integral water } \\
\text { management }\end{array}$ & \multirow{3}{*}{$\begin{array}{ll}- & \text { WB21('99) } \\
- & 4^{\text {th }} \quad \text { National Policy } \\
\text { Memorandum Water } \\
\text { Management ('98) } \\
\text { - } & \text { Delta Plan Rivers }\end{array}$} & $\begin{array}{ll}\text { - Integrated Water } \\
\text { Resource } \\
\text { Management }\end{array}$ \\
\hline $\begin{array}{l}\text { Engineering } \\
\text { approach } \\
\text { Hierarchical } \\
\text { organization (top- } \\
\text { down) }\end{array}$ & & \begin{tabular}{|l|} 
Engineering \\
approach \\
Hierarchical \\
organization (top- \\
down)
\end{tabular} & $\begin{array}{ll}\text { - } & \text { Re-organization } \\
& \text { Rijkswaterstaat } \\
\text { - } & \text { Re-organization } \\
& \text { Regional water boards } \\
\text { - } & \text { Decentralization }\end{array}$ & $\begin{array}{ll}- & \text { Room for Water } \\
- & \text { Democratic } \\
\text { organization } \\
\text { (Stakeholder } \\
\text { participation) }\end{array}$ & & $\begin{array}{ll}\text { - } & \text { Adaptation and } \\
& \text { retention } \\
\text { - } & \text { Participatory Policy } \\
& \text { process }\end{array}$ \\
\hline \multirow[t]{2}{*}{\begin{tabular}{ll}
\multicolumn{2}{l}{ Priorities: } \\
$-\quad$ & Safety \\
- & Agriculture
\end{tabular}} & & $\begin{array}{ll}\text { Priorities: } \\
- & \text { Safety } \\
- & \text { Agriculture } \\
- & \text { Ecology }\end{array}$ & & \begin{tabular}{ll}
\multicolumn{2}{l}{ Priorities: } \\
- & Safety \\
- & Nature \\
& development \\
- & Agriculture \\
- & Spatial Planning
\end{tabular} & & \begin{tabular}{ll}
\multicolumn{2}{l}{ Priorities: } \\
- & Safety \\
- & Spatial Planning \\
- & Nature \\
& development \\
- & Agriculture
\end{tabular} \\
\hline & $\begin{array}{ll}- & \text { Environment dept. in } \\
\text { Delta Dienst } \\
\text { - Dealing with water } \\
\text { ('85) } \\
\text { - Restoration projects }\end{array}$ & & $\begin{array}{ll}- & \text { Plan Ooievaar ('87) } \\
- & \text { Living Rivers ('92) } \\
\text { - } & \text { Dealing with the } \\
& \text { surrounding Area } \\
\text { ('92) }\end{array}$ & & $\begin{array}{llr} & \text { Room for Rivers ('95) } \\
- & \begin{array}{l}\text { Tackling } \\
\text { ('98) }\end{array} & \text { Flooding } \\
\end{array}$ & \\
\hline
\end{tabular}

Table 2. Scheme of developments at three levels of scale (macro, meso, micro) that have influenced the system state of water management in the Netherlands over a time period (1975 - 2004). System states are described in terms of management concept, approach and priorities (1975,1985, 1995, 2004). Based on (Loorbach, 2004) 


\begin{tabular}{lll}
\hline Aspects of Water management & $\mathbf{1 9 7 0} \mathbf{s}$ & $\mathbf{2 0 0 0}$ \\
\hline Problem perception & Singular & Interrelated \\
Management perspective & Problem solving & Anticipation \\
Scale & Local water problem & Water system structure, \\
Management style & Technological solutions & Spatial solutions \\
Strategy & Pumping, drainage, dikes & Retention, natural storage \\
Approach & Planning & Process \\
Competences & Disciplinary & Interdisciplinary \\
Staff & Engineers & Engineers, biologists, public \\
& & managers, spatial planners \\
Institutional Organization & Hierarchical, top down & Networks, participation \\
\hline
\end{tabular}

Table 3. Key aspects and differences between the water management style of the 21st century and the water management style that was dominant throughout the 20th century. Also in this table, the differences are dichotomized for the sake of clarity. A more appropriate conceptualization would be continuous scales.

\section{Water transition management}

Taking the complexity and uncertainty as a starting points, transitions require innovative approaches in order to manage them (Loorbach \& Rotmans, In press; Rotmans, Kemp, \& van Asselt, 2001). Essentially, transition management stimulates transition processes by organizing the build-up of the societal structures needed to realize the new regime. Because the road is unclear, experimentation is essential in order to learn how. Results feedback into the vision, which may then have to be adapted. Experimentation is done in niches that are embedded in larger innovation networks. This coordinated search process must eventually lead to the up-scaling of the innovation networks. Applied to water management this would mean developing strategies that for instance enable the cooperation between spatial planners and water managers. Transition management is based on the following underlying management principles (Rotmans, Loorbach, \&van der Brugge, 2005)

1. The phase of the transition is guiding for the employing management strategies and instruments.

2. A mix of top-down steering, network steering and self-steering instruments should be used, depending on the transition dynamics at hand.

3. Multi-level governance is required in which the objectives and instruments vary at the different levels but have to be attuned to reinforce each other.

4. Stakeholders have to participate and to be aligned

5. Long-term goals must be adaptive to emergent innovations and macrodevelopments.

6. Timing and type of intervention is crucial. Non-equilibrium dynamics should be used to innovate. 
A transition manager tries to combine content with process. He therefore must understand which structures the innovation networks have to be building up and how they can achieve this. It is therefore crucial that he understands transition patterns, e.g. which processes play at each level in each phase. Hence, transitions management is much more than implementing a strategic vision, it is a joint search and learning process directed at developing innovations and new arrangements that will start to reinforce each other. The transition manager thus coordinates multi-actor process at strategic, tactical and operational levels. The operational model developed by (Loorbach \& Rotmans, In press) has four activity clusters (Figure 4): (1) the establishment and development of a transition arena; (2) the creating of long-term integrated visions, transition pathways and agendas; (3) mobilizing actors and knowledge development through experimenting and (4) monitoring and evaluating the transition process.

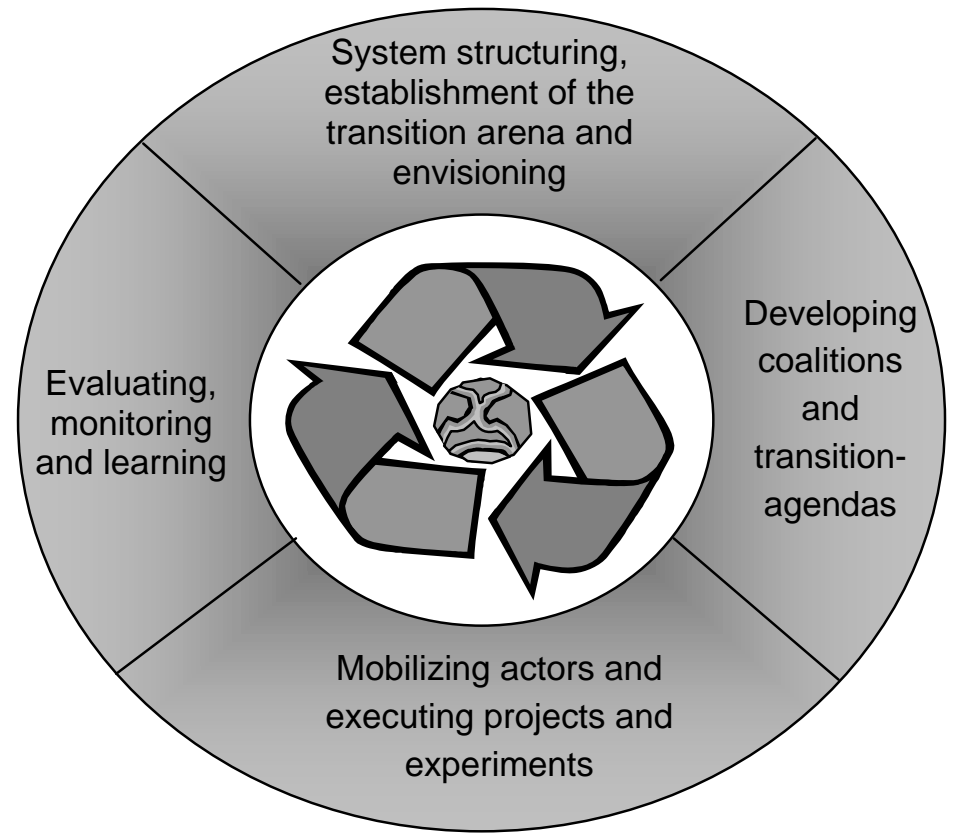

Figure 4. Transition management is a cyclical coordinated multi-actor process at strategic, tactical and operational levels and is organized around four co-evolving activity clusters (1) the establishment and development of a transition arena and envisioning process; (2) developing coalitions, transition pathways and agendas, (3) mobilizing actors and knowledge development through experimenting and (4) monitoring and evaluating the transition process (Loorbach \& Rotmans, In press)

The transition management approach starts with creating a so-called transition arena of 10 to 15 people (Loorbach \& Rotmans, In press; Rotmans et al., 2000). These participants are selected based upon their skills as being able to think across domains, being creative, having relevant knowledge of the field and having networking capabilities. Important is that the transition arena has to be set up outside the traditional institutional settings to avoid early media and political attention that could possibly drain the process. The selected participants should join on personal account rather than representing their home organization or institution, in order to avoid a rather narrow focus on the short-term stakes and vested interests 
of their occupational background. However, the transition arena has to be of a transdisciplinary nature representing different but existing perspectives on the problem.

A transition arena concerning the transition in water management for example might involve policy makers, water engineers, ecologists, spatial planners, landscape architects, farmers, but also experts from related sectors such as the construction sector (housing), urban planners etc. Confrontation between the different perspectives would enrich the problem definition and might lead to alternative 'out of the box' solutions. It is helpful to structure the discussion by using a multi-phase and multi-level system approach in order to give meaning to these developments and understand the direction of its trajectory. Based on the joint representation of the water system sustainability visions for the water system have to be formulated through back - and forecasting methods. The vision consists of a set of qualitative images that illustrate and visualize a future sustainable water system (Dirven et al., 2002) These images should contain physical and spatial elements as well as elements of the new water management style, such as risk management in terms of anticipative and adaptive water management strategies, 'openness' towards other policy domains and institutional organization with regard to participation from stakeholders. Subsequently, transition pathways towards the envisioned system have to be developed. Next, experiments are being set up in order to learn (learning-by-doing and doing-by-learning). Evaluation leads to a next round of experimenting and if necessary the adjustment of the vision.

In the Dutch case, focus now should be on translating the strategy into new institutional regime arrangements and practical instruments for local water managers. Both the institutional arrangements and the instruments have to be developed in co-evolution, so that the institutional arrangements enable the instruments. This is a process that has to be coordinated and is one of the things that is currently lacking in the Netherlands. There is much experimentation going on, but there is a lack of coordination that brings together these learning experiences. Developments that are interesting from this point of view are the water-test that forces water management to be involved in spatial planning and the debate around a merger of regional water management boards with provincial government that is responsible for regional spatial planning. Both the test and the merger influence the transition trajectory but no one seems to be concerned with how they are related, or should be. Yet, the up-scaling of the regional water management boards implies that water managers will increasingly be confronted with existing sectoral and regional policies.

As long as such 'gaps' remain between the strategic level and the operational level, the transition remains in the take-off phase. The institutional structure of the regime is herein a key lever that is decisive in the progress and future direction of the transition. Such institutional changes have serious reinforcing power for the transition when performed well. On the other hand, if ill-performed it can either seriously slow down the transition, or block the desired direction. It therefore is very important to act upon a shared vision of future water management. 


\section{The transition of European Water management}

As we have argued, the problems Dutch water management is being confronted with, are more or less comparable across all European Member States because the problems arise as a result of pressures that are deeply rooted in our modern Western society and a transformation process in which the institutional and technological change hampers. The Water Framework Directive operates against this background. The WFD was an attempt to rethink European water management. On the one hand, the WFD tries to increase the coherence of the fragmented objectives; on the other the European Commission came to recognize that European water policy has to address the increasing awareness of citizens and stakeholders about water. The implementation process of the WFD is a rather complex process in which the institutional arrangements have to change from national geo-political entities into (cross-boundary) river basin management regimes. Its focus is clearly on the upscaling of the ecological approach and to a large extent neglects the spatial dimension of water management. Therefore, it can be argued that the WFD is an important step in the transition towards more adaptive water systems, but still has to undertake the even larger steps in order to involve water quantity issues and the spatial and institutional consequences. To this end it is worthwhile to analyze to what extent the WFD and transition management are based on similar principles.

One of the remarkable things about the WFD is that it is a legislative framework and the transpositions of the EU directives to the member states leaves room to manoeuvre with regard to the form and means of the implementation. At the same time there is the Common Implementation Strategy (CIS), which to some extent seems to be contradictory with this. The results from pilots in nine river basins should lead to a general implementation strategy, which then can be applied to river basins in all Member States. However, there are always differences between river basin management regimes in terms of institutional structures, problems or societal functions. River basins are heterogeneous and may be in very different transitional phases. Particular instruments therefore could be very effective in one of the pilots, but suboptimal in other basins due to local institutional arrangements for instance. The timed usage of various types of instruments may be much more effective and too stringent use of the implementation manual could even hold back desired ongoing developments.

The WFD tries to account for this through public participation. Preamble 14 of the directive states that the overall success of the directive relies on public participation. Subsequently, preamble 46 emphasizes the importance of informing the general public in order to ensure participation in the planning process. The most important article with regard to public participation is article 14 . It prescribes three main forms of participation (2000/60/EC):

- Active involvement in all aspects of the implementation of the Directive, especially - but not limited - to the planning process.

- Consultation in three steps of the planning process

- Access to background information 


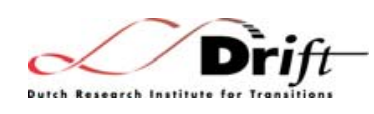

Active involvement means that stakeholders actively participate in the planning process by discussing issues and contributing to the solutions. Consultation means that the public can react to plans and proposals and this should be done at least three times. Access to background information should be given at all times. WFD instructs the Member-States to encourage the first, but ensure the latter two. According to the 'Guidance document on Public Participation' the main reason for public participation is to ensure compliance with the directive: 'Public participation improves decisionmaking by ensuring that decisions are soundly based on shared knowledge, experiences and scientific evidence, that decisions are influenced by the views and experience of those affected by them, that innovative and creative options are considered and that new arrangements are workable and acceptable to the public'. Transition management recognizes the need for sharing knowledge, however, this does not necessarily guarantee innovation. One of the reasons explaining why the water-related problems are persistent, is the strong interconnectivity and the internal logic of the existing institutions. Changing one piece of the puzzle requires many more pieces to change in order to make the puzzle fit again. It can be argued that the participatory process prescribed by the WFD does not stimulate innovation, since predominantly traditional stakeholders are involved, e.g. stakeholders with particular interests in the current regime. Stakeholder evaluation could block radical innovative options because they do not 'fit' their vested interests. Stakeholder participation is absolutely necessary but can also block the path towards fundamental institutional change. In order to overcome the stakeholder dilemma, a transition arena should not involve stakeholders with vested interests, but innovative niche players. Allowing them to carry out experiments, they are able to develop knowledge and experience, to create networks, to communicate and to improve skills, e.g. build up an infrastructure. Developing these innovations in terms of network externalities and learning experiences makes it less costly and more attractive for actors to eventually join the innovation network.

Table 4. shows some differences between the WFD and transition management applied to the field of water management. Both in terms of the content as in terms of the nature of the process the overall objective is different. The WFD is concerned with good quality status for all waters, meaning general protection of the aquatic ecosystem, specific protection of valuable habitats, protection of drinking water resources and bathing water. The objective of transition Management is developing sustainable and adaptive water systems. Although both consider the river basin the optimal unit for water management, the implications for the process are profound. Transition management tries to develop strategies to integrate water quality, water quantity and the societal functions the water provides the region. From a transition management perspective, this requires a transformation of two co-evolving systems, namely the societal system and the aquatic ecosystem. The WFD mainly considers the process to be a one-directional implementation process of water quality standards (although this may have consequences for water functions). Participation is needed in order to facilitate and legitimize the process. As argued, this could reinforce existing power configurations, instead of transforming them. 
Another difference is the time horizon used in the transition management and the WFD. The WFD has to be implemented in 2015. From then on, every six years the river basin management plan has to be revised. Although transition management can also be divided in development rounds of approximately five years, these rounds are more or less ongoing and cyclic. There is a constant iteration process between learning experiences and the long-term vision. The long terms goals are guiding for the short term, but also adaptive to new developments and experiences. Using only the tight time-schedule planning and implementation every six years may again excludes innovations that take more time to develop.

\begin{tabular}{|c|c|c|}
\hline & WFD & Transition management \\
\hline Objectives & Good quality for all waters & Adaptive water systems \\
\hline Means & $\begin{array}{l}\text { Integrating water quality } \\
\text { directives }\end{array}$ & $\begin{array}{l}\text { Integrating ecological, } \\
\text { economic and socio-cultural } \\
\text { water functions }\end{array}$ \\
\hline Management unit & River basin management & $\begin{array}{l}\text { Integrated water system } \\
\text { approach }\end{array}$ \\
\hline Problem perception & Implementation problem & Persistent problem \\
\hline Process & $\begin{array}{l}\text { Decision making process and } \\
\text { implementation of River basin } \\
\text { management plan }\end{array}$ & Transition processes \\
\hline Approach & $\begin{array}{l}\text { Management boards, Advisory } \\
\text { boards and public } \\
\text { participation }\end{array}$ & $\begin{array}{l}\text { Transition arena, coalitions, } \\
\text { innovation networks and } \\
\text { development rounds }\end{array}$ \\
\hline Participation & $\begin{array}{l}\text { Balancing interests and } \\
\text { increasing public support }\end{array}$ & $\begin{array}{l}\text { Dealing with complexity } \\
\text { uncertainty and pluralism }\end{array}$ \\
\hline Participatory process & $\begin{array}{l}\text { Consulting parties based on } \\
\text { draft River basin management } \\
\text { plan }\end{array}$ & $\begin{array}{l}\text { Co-production of visions, } \\
\text { strategies and experimenting } \\
\text { (learning-by-doing) }\end{array}$ \\
\hline Time horizon & $\begin{array}{l}\text { Implementation of WFD by } \\
\text { 2015. River basin management } \\
\text { plans every six years. }\end{array}$ & $\begin{array}{l}\text { Long term perspective } \\
\text { ( } 30 \text { years) and time-varying } \\
\text { development rounds }\end{array}$ \\
\hline
\end{tabular}

Table 4. Key aspects and differences between the Water Framework Directive and Transition management Also in this table, the differences are dichotomized for the sake of clarity. A more appropriate conceptualization would be continuous scales.

\section{Conclusions}

Due to the increasing complexity of our modern society, water functions are becoming more and more interrelated. European water management is being confronted with complex, uncertain and multi-facetted problems when solving water related problems. The persistence of these problems is caused by the strong interwovenness of water institutions, management structures and dominant practices 
throughout the water system. This results in a tight and well-organized water management regime of policy departments, regional water management boards, engineering offices, which is hard to change. Due to this so-called regime structure radical innovations have trouble to break through and change the dominant way of doing things.

The particular case of the Netherlands generates insights into the general nature of the transition process of European water management and showed that persistent problems require innovative approaches, such as transition management. The transition analysis shows that the Dutch transition is in the take-off phase and near the acceleration phase. The new water management strategy, such as the retentionstore-drain strategy, broadening of riverbeds, the designation of flood-areas and cooperation between water managers with spatial planners seem to be accepted. Nonetheless, the change of actual practices remains difficult because there are considerable gaps between abstract strategies, the enabling institutions and practice, hampering the shift towards the acceleration phase.

There are differences and similarities between transition management and the European Framework Directive. Although the WFD does stimulate forms of integration and participation, the current format might not create the innovative climate necessary for transition processes. Enriching the WFD with transition management principles may help to improve that.

\section{Acknowledgements}

The authors would like to thank the reviewers for their useful and constructive comments. The authors also thank Flor Avelino and Derk Loorbach.

\section{References}

Arthur, B. W. (1988). Competing technologies. In G. Dosi (Ed.), Technological change and economic development. London/ New York: Printer.

Berkhout, F., Smith, A. en Stirling, A. (2003). Socio-technical regimes and transitions contexts. SPRU Electronic Working Paper Series.

Bosch, A., \& Ham, W. v. d. (1998). Twee eeuwen Rijkswaterstaat, 1798-1990. (Two centuries Rijkswaterstaat, 1798-1990). Zaltbommel: European Library.

Bruijn, D. d., Hamhuis, D., Nieuwenhuijze, L. v., Overmars, W., Sijmons, D., \& Vera, F. (1987). Ooievaar: De toekomst van het Rivierengebied. (Stork: the future of the riverland). Arnhem, The Netherlands: Gelderse Milieufederatie.

Dirven, J., Rotmans, J., \& Verkaik, A. (2002). Samenleving in transitie: Een vernieuwend gezichtspunt (Essay). Den Haag: Innovatienetwerk Agrocluster en Groene Ruimte.

EC. (2000). EU Water Framework Directive (No. 2000/60/EC). Brussels.

Geels, F. W., \& Kemp, R. (2000). Transities vanuit sociotechnisch perspectief (Essay). Maastricht: MERIT. 
Gersick, C. J. G. (1991). Revolutionary change theories: a multi-level exploration of the punctuated equilibrium paradigm. The academy of management review, 16(1), 1036.

Ham, W. v. d. (1999). Heersen en Beheersen, Rijkswaterstaat in de twintigste eeuw. (Rule and Control, Rijkswaterstaat in the 20th century). Zaltbommel, The Netherlands: European Library.

Holland, J. H. (1995). Hidden Order: How Adaptation Builds Complexity. Cambridge, Massachusetts: Helix books / Perseus books.

Kauffman, S. (1995). At home in the universe: the search for laws of complexity. Oxford: Oxford University Press.

Kemp, R., Schot, J ., \& Hoogma, R. (1998). Regime shifts to sustainablilty through processes of niche formation: the approach of strategic niche management. Technology analysis and strategic management, 10, 175-196.

Lintsen, H. (2002). Two centuries of central water management in the Netherlands. Technology and Culture, 43, 549-568.

Loorbach, D., \& Rotmans, J . (In press). Managing transitions for Sustainable Development. In A. J. Wieczorek \& X. Olsthoorn (Eds.), Industrial Transformation - Disciplinary approaches towards transformation research: Kluwer.

Luhmann, N. (1984). Soziale Systemen. Frankfurt: Suhrkampf.

Nelson, R. R., \& Winter, S. G. (1982). An evolutionary theory of economic change. Cambridge, Massachusetts: Belknap Press of Harvard University Press.

Prigogine, I., \& Stengers, I. (1984). Order out of chaos: man's new dialogue with nature. Boulder: C.O. New Science Library.

Ravetz, J. R. (1999). What is Post-Normal Science. Futures, 31(7), 647-653.

Rijkswaterstaat. (1964). Eerste nota Waterhuishouding (1st national policy memorandum on water management). The Hague: Ministry of Transport, Public Works and Water Management.

Rijkswaterstaat. (1982). Tweede nota Waterhuishouding (2nd national policy memorandum on water management). The Hague: Ministry of Transport, Public Works and Water Management.

Rijkswaterstaat. (1989). Derde nota Waterhuishouding (3rd national policy memorandum on water management). The Hague: Ministry of Transport, Public Works and Water Management.

Rijkswaterstaat. (1992). Omgaan met de Omgeving (Dealing with the surrounding area). The Hague, The Netherlands: Ministry of Transport, Public Works and water management.

Rijkswaterstaat. (1998). Vierde nota Waterhuishouding (4th national policy memorandum on water management). The Hague: Ministry of Transport, Public Works and Water Management.

RIZA. (1985). Omgaan met water (Dealing with water). The Hague, The Netherlands: Rijkswaterstaat. 
Rotmans, J. (1994). Transitions on the move. Global Dynamics and Sustainable Development. Bilthoven, The Netherlands: Rijksinstituut voor Volksgezondheid en Milieu.

Rotmans, J., Kemp, R., \& van Asselt, M. (2001). More evolution than revolution: Transition management in public policy. Foresight, 03(01), 17.

Rotmans, J., Kemp, R., van Asselt, M., Geels, F., Verbong, G., \& Molendijk, K. (2000). Transitions \& transition management: the case of a low emission energy supply. Maastricht: ICIS / MERIT.

Rotmans, J., Loorbach, D., \& van der Brugge, R. (2005). Transitiemanagement en duurzame ontwikkeling: Co-evolutionaire sturing in het licht van complexiteit. Beleidswetenschap.

Sabatier, P. A., \& J enkins-Smith, H. C. J . (1999). The Advocacy Coalition Framework, an assessment. In P. A. Sabatier (Ed.), Theories of the policy process. Oxford: Westview Press.

Saeijs, H. L. F. (1991). Integrated water management. A new concept: from treating of symptoms towards a controlled ecosystem management in the Dutch delta. Lands Urban Plan, 20, 245-255.

Smits, R., \& Kuhlmann, S. (2004). The rise of systemic instruments in innovation policy. The International J ournal of Foresight and Innovation Policy, 1(1/2), 4-32.

Van der Brugge, R., Rotmans, J., \& Loorbach, D. (2005). The transition in Dutch water management. Regional Environmental Change, Online first(1).

Varela, F., Maturana, H., \& Uribe, R. (1974). Autopoiesis: The organization of living systems, its characterization and a model. Biosystems, 5, 187-196.

WWF. (1992). Levende Rivieren (Living rivers). Zeist, The Netherlands: World Wildlife Fund. 